\title{
Strategi Pengembangan Ekonomi Mualaf di Kota Padang
}

\author{
M. Zaky Mubarak Lubis \\ Fakultas Ekonomi dan Bisnis Islam \\ UIN Imam Bonjol Padang
}

Korespodensi dengan Penulis:

M. Zaky Mubarak Lubis: Telp: 082268098966

E-mail: zakylubis@uinib.ac.id

\section{Keywords: Mualaf, Islamic Economy, Padang.}

Kata kunci: Mualaf, Ekonomi Islam, Padang

\begin{abstract}
This study aims to find the economic development strategies of converts in the city of Padang. The research approach was conducted using a descriptive qualitative method by collecting data through interviews, documentation and focus group discussions. The research explains that the economic problems of converts to cities in the city are caused by the severance of family relations, lack of ability, lack of converts, lack of assistance and lack of community awareness. The strategy in the economic development of converts in the city of Padang is happy with four processes. First, the making of converts as a means of gathering converts and becomes problem solving for all converts in the city of Padang. Second, capacity building is carried out by conducting trainings that provide the ability of converts so that converts have the opportunity to make a business. Third, the provision of financial assistance aims to enable the ability of entrepreneurs who have been trained to be implemented in the form of business through financial assistance from both the government and the private sector. Fourth, supervision and assistance to the business carried out by converts in order to survive and be developed so that they can help other converts. To see the effects of the concept of this strategy it is necessary to implement all of these strategies so that they can be assessed and evaluated in an effort to improve the economy of converts.
\end{abstract}

\begin{abstract}
Abstrak
Penelitian ini bertujuan untuk menemukan strategi pengembangan ekonomi mualaf yang ada di Kota Padang. Pendekatan penelitian dilakukan metode deskriptif kualitatif dengan pengumpulan data melalui wawancara, dokumentasi dan focus group discussion. Penelitian menjelaskan bahwa problematika ekonomi mualaf di Kota Padang disebabkan oleh pemutusan hubungan keluarga, rendahnya kemampuan, belum adanya organisasi mualaf, minimnya bantuan dan
\end{abstract}


minimnya kepedulian masyarakat. Strategi dalam pengembangan ekonomi mualaf di Kota Padang terbagi atas empat proses. Pertama, pembuatan organisasi mualaf sebagai sarana dalam mengumpulkan mualaf dan menjadi problem solving untuk semua mualaf yang ada di Kota Padang. Kedua, peningkatan kapasitas dilakukan dengan mengadakan pelatihan-pelatihan yang memberikan kemampuan pada mualaf sehingga mualaf mempunyai peluang dalam membuat usaha. Ketiga, pemberian bantuan dana bertujuan agar kemampuan wirausaha yang telah dilatih dapat diimplementasikan dalam bentuk usaha melalui bantuan dana baik dari pihak pemerintah maupun swasta. Keempat, pengawasan serta pendampingan terhadap usaha yang dijalankan oleh mualaf agar dapat bertahan dan dikembangkan sehingga bisa membantu muallaf lain. Untuk melihat efek dari konsep strategi ini maka diperlukan implementasi dari semua strategi tersebut sehingga dapat dinilai dan dievaluasi dalam upaya peningkatan ekonomi mualaf.

\section{PENDAHULUAN}

Ajaran Islam sebagai rahmatan lil'alamin menjadikannya sebagai agama yang dapat diterima oleh seluruh umat di dunia termasuk orang-orang yang beragama selain Islam. Sebagai efeknya tidak jarang orang yang berlatar belakang agama lain berpindah keyakinan menjadi Islam. Fenomena tersebut mulai banyak muncul dalam kehidupan keagamaan saat ini. Disebabkan semakin tersebarnya dakwah Islam melalui kajian-kajian dengan berbagai macam media yang ada baik media konvensional maupun media elektronik. Hal tersebut menjadikan banyak orang yang semakin tercerahkan dan memahami tentang Islam sehingga membuat orang-orang tertarik dan dapat berpindah ke dalam ajaran Islam.

Pada dasarnya, kata mualaf merujuk kepada orang-orang yang mendapatkan keIslamannya tidak berdasarkan keturunan. Dalam artian bahwa seseorang yang dikatakan mualaf adalah orang yang pada saat dilahirkan telah menganut kepercayaan lain (bukan Islam). Sedangkan secara teoritis, sebenarnya mualaf adalah orang-orang yang dibujuk hatinya untuk masuk Islam. Dalam pengertian ini, orang yang belum masuk Islam tetapi hatinya sudah memiliki kecondongan untuk masuk Islam sudah dapat dimasukkan dalam kategori mualaf. Demikian juga orang yang baru masuk Islam tetapi hatinya masih memiliki keraguan tentang Islam masih termasuk dalam kategori mualaf. ${ }^{1}$

1 Sri Hidayati, "Problematika Pembinaan Mualaf di Kota Singkawang dan Solusinya melalui Program Konseling Komprehensif”, Jurnal Dakwah, Vol. XV, No. 1, 2014. hlm. 112. 
Beberapa penelitian menunjukkan perkembangan mualaf yang ada di Indonesia secara umum dan beberapa daerah secara khusus. Menurut Syarifah² (2017), berdasarkan data Mualaf Center Indonesia (MCI), setidaknya sepanjang 2016 terdapat orang yang masuk Islam sebanyak 2.857 melalui wadah MCI. Hal ini mengalami kenaikan sebesar 5 persen dibandingkan pada tahun sebelumnya. Sedangkan jika dirunut dari tahun 2011, setidaknya terdapat kurang lebih 10.000 orang yang masuk Islam melalui wadah MCI. Penelitian lain yang dilakukan Sri Hidayati ${ }^{3}$ (2014), jumlah mualaf di Kota Singkawang, yaitu mencapai 630 orang berdasarkan data Kementrian Agama. Sedangkan berdasarkan dara PITI (Pembina Iman Tauhid Islam) Kota Singkawang bahwa jumlah mualaf di Kota Singkawang mencapai jumlah lebih dari 1000 orang. Dari jumlah tersebut, mayotritas adalah adalah dari etnis Tionghoa dan sebagian lainnya adalah etnis Dayak, Jawa, dan Batak. Penelitian yang dilakukan Saprillah4 (2016), mualaf di Tagari Lonjo, Kelurahan Pengawu, Palu Selatan mencapai 200 orang. Mereka berasal dari Suku Kaili sub Suku Daa yang bermukim di Desa Pemantuma di pegunungan Palu.

Tabel 1. Data Mualaf Kota Padang dari 2010-2016

\begin{tabular}{llc}
\hline No & Kecamatan & Jumlah Mualaf \\
\hline 1 & Bungus & 6 \\
2 & Padang Utara & 7 \\
3 & Lubuk Kilangan & 13 \\
4 & Padang Barat & 10 \\
5 & Kuranji & 33 \\
6 & Padang Selatan & 30 \\
7 & Padang Timur & 51 \\
8 & Lubuk Begalung & 46 \\
9 & Nanggalo & 9 \\
10 & Pauh & 3 \\
11 & Koto Tangah & 27 \\
\hline Total & & 235 \\
\hline
\end{tabular}

Sumber: Kemenag Kota Padang

Sedangkan untuk Provinsi Sumatra Barat yang kaya akan nilai adat basandi syara' dan syara' basandi kitabullah perkembangan mualaf cukup pesat. Salah satu kota di wilayah Provinsi Sumatra Barat yang memiliki jumlah mualaf terbanyak adalah Kota Padang. Hal ini dapat dilihat

2 Hidayatus Syarifah, "Pendidikan Agama Islam bagi Mualaf di Pesantren Pembinaan Mualaf Yayasan An-Naba Center Indonesia", Tesis, UIN Syarif Hidayatullah Jakarta, 2017. hlm. 3.

${ }^{3}$ Sri Hidayati, Problematika Pembinaan Mualaf, hlm. 112.

4 Saprillah, "Pengelolaan Mualaf dan Problematikanya di Kota Palu", Jurnal Al-Fikr, Vol. 20, No. 2, 2016. hlm. 192. 
dari data Kementrian Agama. Kota Padang memiliki persentase jumlah mualaf tertinggi dibandingkan dengan dua kota besar lainnya, yaitu Kota Padang 65,7\%, Kota Payakumbuh 14,38\% dan Kota Bukittinggi 20\%. Jumlah mualaf Kota Padang sampai 2017 adalah 235 orang. ${ }^{5}$

Meskipun demikian, perkembangan mualaf tersebut juga memunculkan problematika. Menurut Supriadi (2018) ${ }^{6}$, Hafizh (2017)7, Andi Fitriyani dkk (2019) ${ }^{8}$, Rosyida (2018)9 , Lucky (2018)10, Titian Hakiki dan Rudi Cahyono (2015)11, Lilik dan Wida (2015) ${ }^{12}$ ada beberapa problematika yang dihadapi para mualaf yaitu tekanan dari keluarga, isolasi lingkungan sosial, masih rendahnya pemahaman keagamaan, masalah ekonomi dan keuangan, ajakan untuk kembali pada agama yang lama, masih rendahnya kepedulian muslim terhadap mualaf dan masih rendahnya pembinaan yang diberikan.

Berbagai macam problematika yang dihadapi oleh mualaf membutuhkan penanganan yang serius sebab apabila mualaf tidak ditangani secara baik maka akan memungkinkan untuk para mualaf kembali pada keyakinan mereka yang lama. Sebagai salah satu bentuk penjagaan mualaf tersebebut dibutuhkan peranan berbagai pihak terutama pemerintah. Untuk Kota Padang, sebagai bentuk penjagaan terhadap mualaf diadakanlah pembinaan mualaf pada 10-12 September 2019 dengan peserta sebanyak 120 orang. ${ }^{13}$ Pembinaan dilakukan dalam meningkatkan kapasitas mualaf Kota Padang dalam menjalani kehidupan. Dari survei sederhana yang dilakukan saat pembinaan yang dilakukan, problematika yang menjadi masalah utama

${ }^{5}$ Alfenia, "Gambaran Religiusitas Individu yang Menjalani Konversi Agama lain ke Islam (Mualaf) di Kota Padang", Thesis, Universitas Andalas. 2018. hlm. 4.

${ }^{6}$ Supriadi, "Problematika Mualaf dalam Melaksanakan Ajaran Agama Islam di Desa Tumbang Runen Kecamatan Kamipang Kabupaten Katingan", Jurnal Hadratul Madaniyah, Vol. 5, No. 1, 2018. hlm. 4144.

7 Hafidz Muhdhori, "Treatment dan Kondisi Psikologis Mualaf", Jurnal Edukasi: Media Kajian Bimbingan Konseling, Vol. 3, No. 1, hlm. 16-39.

8 Andi Fitriyani dkk, "Pendampingan dan Pembinaan Komunitas Mualaf melalui Pembibitan Perangkat Syara' di Desa Wamana Baru Kec. Fena Leisela Kab. Buru, Maluku", Dialektika: Jurnal Pemikiran Islam dan Ilmu Sosial, Vol. 12, No. 01, 2019. hlm. 11-25.

9 Rosyida Nur Azizah, "Sikap Keberagamaan Mualaf Di Kabupaten Banyumas (Studi Fenomenologi)", Tesis, IAIN Purwokerto, 2018. hlm. 3.

${ }^{10}$ Lucky Prihartanto, "Komitmen Religius Mualaf yang Mengikuti Program Pembinaan Mualaf di Masjid Nasional Al-Akbar Surabaya (Ditinjau dari Teori Religious Commitment Stark \& Glock)", Tesis, UIN Sunan Ampel Surabaya, 2018.

11 Titian Hakiki dan Rudi Cahyono, "Komitmen Beragama pada Mualaf (Studi Kasus pada Mualaf Usia Dewasa", Jurnal Psikologi Klinis dan Kesehatan Mental, Vol. 4, No. 1, 2015. hlm. 20.

12 Lilik Kholisotin dan Wida Kusniawati, "Problematika Mualaf dalam Melaksanakan Ajaran Islam Didesa Tumbang Runen Kecamatan Kamipang Kabupaten Katingan", Jurnal Hadratul Madaniyah, Vol. 5, No. 1, 2018.

${ }^{13}$ Pembinaan Mualaf Kota Padang dilaksanakan oleh Dinas Sosial, 10-12 September 2019. 
mualaf Kota Padang adalah problematika ekonomi. Hal ini memiliki efek yang sangat besar dalam kehidupan para mualaf sehingga diperlukan strategi tentang bagaimana pengembangan ekonomi para mualaf di Kota Padang. Tulisan ini berupaya menjelaskan strategi-strategi yang dapat dilakukan dalam upaya peningkatan ekonomi mualaf yang ada di Kota Padang.

Grafik 1. Problematika Mualaf Kota Padang

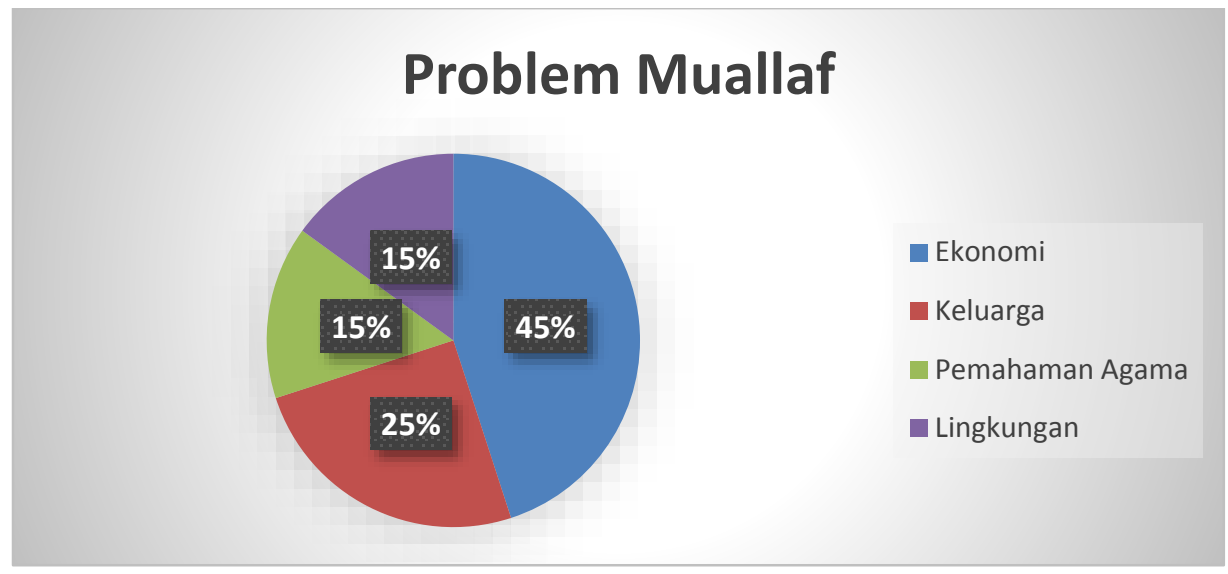

\section{METODE}

Penelitian ini menggunakan metode deskriptif kualitatif. Hal ini disebabkan peneliti bermaksud menggambarkan bagaimana upaya yang dapat dilakukan dalam pengembangan ekonomi mualaf yang ada di Kota Padang. Penelitian deskriptif kualitatif adalah penelitian yang menggambarkan atau melukiskan objek penelitian berdasarkan fakta-fakta yang tampak atau sebagaimana adanya. ${ }^{14}$ Penelitian deskriptif kualitatif berusaha mendeskripsikan seluruh gejala atau keadaan yang ada, yaitu keadaan gejala menurut apa adanya pada saat penelitian dilakukan. ${ }^{15}$

Teknik pengumpulan data yang digunakan dalam penelitian ini adalah

a) Dokumentasi dengan cara mengumpulkan sumber-sumber dan bahan yang relevan berkaitan dengan strategi pemberdayaan ekonomi mualaf yakni berupa jurnal-jurnal terkait dengan permasalahan mualaf

b) Wawancara yaitu menggali data dengan melakukan wawancara dengan orang-orang yang terkait dengan penelitian. Wawancara dilakukan dengan dua orang pegawai dinas sosial Kota Padang dan enam orang mualaf yang menjadi koordinator pada saat pelatihan berlangsung.

${ }^{14}$ Hadari Nawawi dan Mini Martini, "Penelitian Terapan", (Yogyakarta: Gajah Mada University Press, 1996). hlm. 73.

${ }^{15}$ Mukhtar, "Metode Penelitian Deskriptif Kualitatif”, (Jakarta: Gp Press Group, 2013), hlm. 28. 
c) Focus Group Discussion (FDG) dalam rangka menemukan makna sebuah isu oleh sekelompok orang lewat diskusi untuk menghindari diri pemaknaan yang salah oleh seorang peneliti. FGD dilakukan dengan dosen dan orang-orang yang pernah terlibat dalam pemberdayaan.

Teknik analisis data yang dilakukan sebagai berikut ${ }^{16}$

a) Data reduction, yaitu penulis memilih dan memilah-milah data yang sesuai dengan strategi pengembangan mualaf;

b) Data display, yaitu penulis menampilkan data yang telah dipilih dan dipilah-pilah dan menganalisis bermacam strategi yang dapat dijalankan dalam rangka pengembangan ekonomi mualaf;

c) verification, yaitu penulis menyimpulkan hasil analisis terhadap strategi pengembangan ekonomi mualaf.

\section{HASIL DAN PEMBAHASAN}

\section{Kompleksitas Masalah Mualaf Kota Padang}

Berdasarkan data survei saat pembinaan mualaf yang ada dalam pendahuluan, problematika ekonomi menjadi masalah utama yang dihadapi para mualaf. Saat mualaf memutuskan untuk pindah agama, maka mereka akan terlepas dari keluarga. Hal tersebut secara tidak langsung juga menyebabkan para mualaf terbebas dari bantuan ekonomi. Dalam era kehidupan yang serba materil saat ini, kebutuhan ekonomi merupakan hal primer. Segala kebutuhan membutuhkan kemampuan ekonomi yang kuat. Apalagi bagi mualaf yang baru memulai estafet baru dalam kehidupannya. Seorang mualaf harus mempunyai kemampuan ekonomi yang cukup untuk menyokong kehidupannya. Apabila problematika ekonomi tidak diselesaikan secara baik, secara jangka panjang apabila mualaf tidak memiliki kemampuan ekonomi yang baik maka dapat menyebabkan mualaf kembali pada keyakinan lama.

Berdasarkan penuturan para peserta pembinaan ada beberapa faktor yang menjadi penyebab timbulnya problematika ekonomi para mualaf:

a) Pemutusan hubungan oleh keluarga. Keputusan seorang mualaf untuk berpindah agama menjadi muslim memiliki konsekuensi yang sangat besar dalam hidup. Salah satunya adalah putusnya hubungan dengan keluarga asli. Orang-orang yang telah berpindah agama akan kehilangan akses dengan keluarga yang lama termasuk akses ekonomi. Hal ini menyebabkan mualaf mengalami kendala dalam menjalani kehidupan yang baru. Sebagai contoh salah satu peserta pembinaan yang berasal Jakarta. Setelah

\footnotetext{
${ }^{16}$ Ibid., hlm. 135.
} 
memutuskan menjadi mualaf, diusir dari keluarga dan pindah kepadang tanpa bekal apapun. Hal tersebut menjadikan masalah bagi pengembangan kehidupannya kedepan. Selain itu seorang peserta dari Medan yang masih berstatus mahasiswa, setelah menjadi mualaf segala kebutuhan pendidikan diputuskan oleh keluarga asli. Sebagai efeknya dia harus bersusah payah dalam melanjutkan perkuliahan karena mencari pekerjaan sampingan juga sulit didapatkan. Contoh tersebut memperlihatkan bahwa bagi mualaf yang belum memiliki kemapanan ekonomi yang baik, pemutusan hubungan dalam segala aspek oleh keluarga asal termasuk dalam hal ekonomi menjadi kendala dalam mempertahankan hidup dan status mualaf.

b) Masih rendahnya kemampuan yang dimiliki mualaf. Menjadi seorang mualaf merupakan sebuah prestasi dan anugerah yang sangat besar. Hal itu disebabkan tidak semua orang mendapatkan hidayah untuk bisa berpindah dari keyakinan lama menjadi Islam. Akan tetapi, langkah selanjutnya adalah bagaimana melanjutkan kehidupan sebagai seorang muslim. Kenyataan semakin terbatasnya lapangan pekerjaan dan semakin berkembangnya kemampuan yang dibutuhkan seperti kemampuan teknologi dan bahasa, juga dihadapi oleh para mualaf. Masih terbatasnya kemampuan dan skill yang dimiliki mualaf membuat peluang mereka dalam pengembangan ekonomi menjadi terhambat sehingga dibutuhkan penguatan kemampuan mualaf sesuai dengan tuntutan kehidupan pada saat ini.

c) Belum adanya wadah khusus mualaf di Kota Padang. Berkembangnya mualaf di kota Padang tidak terfasilitasi secara kelembagaan. Dalam pembinaan tersebut, diketahui bahwa sampai saat ini belum ada forum mualaf. Sebuah wadah yang berisi para mualaf yang terorganisir sehingga mereka dapat saling bersinergi dalam mengatasi masalah yang dihadapi. Tanpa adanya hal tersebut selain mualaf tidak terorganisir secara baik, juga akan berimbas pada minimnya bantuan pada mualaf. Disebabkan pola bantuan yang ada saat ini lebih lazim diberikan pada kelompok maupun lembaga. Selain itu meskipun data kemenag telah menunjukkan data mualaf, diyakini masih ada mualaf yang belum terdata disebabkan belum adanya forum mualaf tersebut.

d) Masih minimnya bantuan ataupun akses pendanaan bagi mualaf. Berdasarkan penuturan para peserta, upaya pemerintah Kota Padang dalam mengumpulkan dan membina merupakan suatu langkah yang baik. Akan tetapi, tindak lanjut yang lebih diinginkan oleh para mualaf adalah adanya bantuan dalam bentuk pendanaan baik berupa hibah maupun pinjaman lunak. Hal tersebut memungkinkan para mualaf untuk dapat mengembangkan kehidupan dan mengubah keadaan ekonomi. Adanya akses 
dana dapat menjadi awal bagi mualaf dalam membuat suatu usaha yang menghasilkan disertai dengan pendampingan yang memadai.

e) Masih rendahnya kepedulian sesama muslim di Kota Padang. Dalam pandangan peserta kepedulian yang dimaksudkan adalah bantuan dalam bentuk materi. Tidak dapat dipungkiri semakin beratnya kehidupan dan ditambah dengan semakin tingginya sifat individualistis dalam kehidupan saat ini. Sebagai efeknya bukan hanya mualaf tapi pada warga muslim lainpun terkadang kepedulian masyarakat menjadi berkurang. Hal ini menjadi sebuah kendala yang dialami mualaf.

\section{Strategi Pengembangan Ekonomi Mualaf}

Melihat problematika tersebut maka diperlukan strategi sebagai upaya dalam pengembangan ekonomi mualaf. Merujuk pada pandangan Mardi Yatno Hutomo tentang strategi pemberdayaan ekonomi masyarakat bahwa terdapat dua pola yang dapat dilakukan ${ }^{17}$

a) Memberikan bantuan motivasi moril. Motivasi moril merupakan upaya penjabaran tentang fungsi, hak dan kewajiban manusia dalam hidupnya. Inti dari hal tersebut adalah manusia diwajibkan beriman, beribadah, bekerja dan berikhtiar dengan sekuat tenaga sedangkan hasil akhir dikembalikan kepada Dzat yang Maha Pencipta. Metode yang pertama ini termasuk dalam pemberdayaan jangka pendek. Bentuk-bentuk motifasi moril itu adalah:

i. Pelatihan Usaha. Melalui pelatihan ini setiap peserta diberikan pemahaman terhadap konsep-konsep kewirausahaan maupun kemampuan menghasilkan lainnya dengan segala macam seluk beluk permasalahan yang ada didalamnya. Tujuan pelatihan ini adalah untuk memberikan wawasan yang lebih menyeluruh dan aktual sehingga dapat menumbuhkan motivasi terhadap masyarakat disamping diharapkan memiliki pengetahuan taknik kewirausahaan dalam berbagai aspek.

ii. Permodalan. Permodalan dalam bentuk uang merupakan salah satu faktor penunjang dalam usaha manusia. Diperlukan bamtuan dana yang dapat dimanfaatkan bagi mualaf dalam upaya pengembangan usaha. Bantuan dapat berubah hibah maupun skema pinjaman lunak.

b) Memberikan bantuan pendidikan. Perbaikan pendidikan akan dapat membantu seseorang dalam peningkatan kualitas hidup. Semakin tinggi pendidikan maka peluang

17 Mardi Yatmo Hutomo, "Pemberdayaan Masyarakat Dalam Bidang Ekonomi", (Yogyakarta: Adiyana Press, 2000), hlm. 38-39. 
untuk peningkatan hidup akan dapat dilakukan. Pemberian akses pendidikan pada para mualaf juga dapat menjadi akselerasi perbaikan ekonomi secara jangka panjang.

Kemudian, berdasarkan konsep tersebut, strategi pengembangan ekonomi yang dapat dilakukan untuk mualaf di kota Padang adalah sebagai berikut

a) Pembenahan sumber daya manusia mualaf

Langkah pertama yang dilakukan dalam pengembangan ekonomi mualaf adalah pembuatan Forum Mualaf. Forum Mualaf bertujuan untuk menjadi wadah bagi semua mualaf yang ada di Kota Padang. Dengan beban psikologis yang masih dimiliki oleh mualaf, adanya wadah yang berisi orang-orang yang memiliki nasib yang sama akan mempermudah para mualaf untuk saling mengenal dan menguatkan antara satu dan lainnya. Setelah adanya Forum Mualaf maka diperlukan pembuatan database mualaf yang di kota Padang sehingga dapat diproyeksikan bagaimana tindakan pemberdayaan yang akan dilakukan untuk para mualaf.

Gambar 2. Skema Forum Mualaf

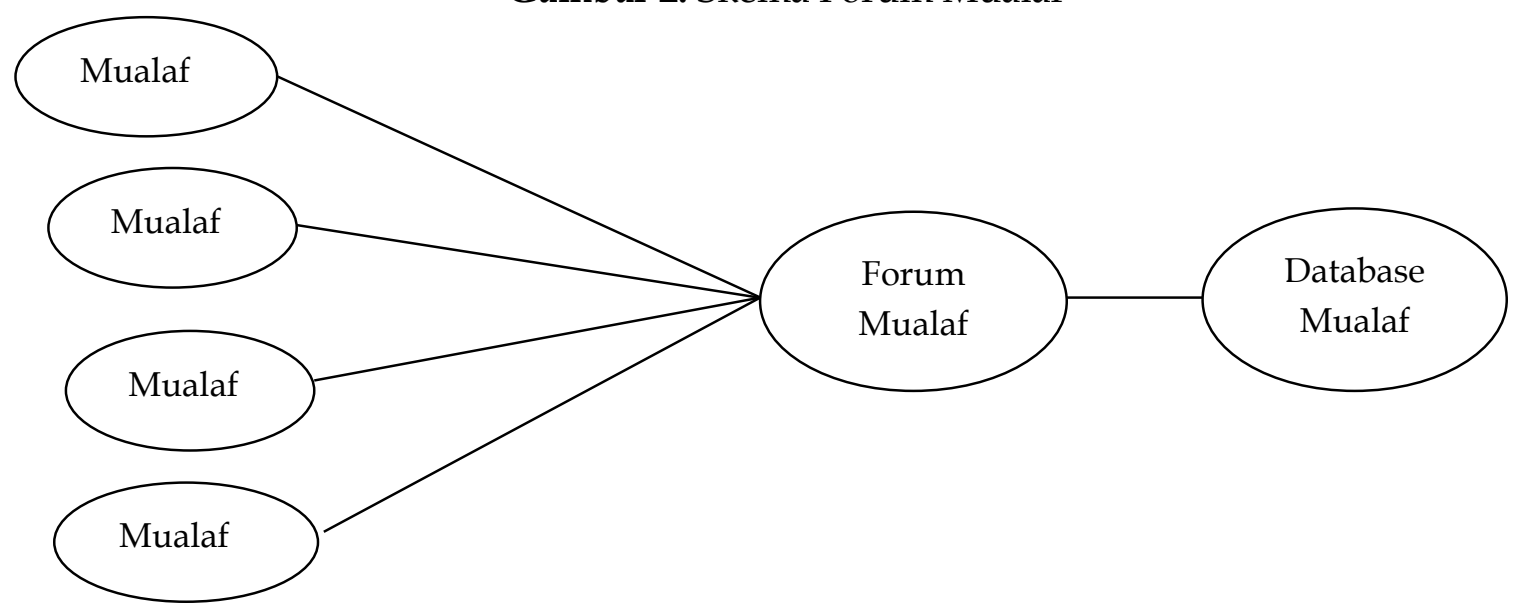

Sumber: Analisis peneliti, 2019

Database berisi tentang data lengkap para mualaf sehingga dapat dipetakan keadaan mualaf yang ada seperti skill dan kemampuan yang dimiliki dan bagaimana pendapatan dan pekerjaan yang telah dimiliki. Tujuannya agar didapatkan treatment yang sesuai untuk mualaf kota Padang. Sebagai contoh adalah Forum Mualaf Aceh (Formula), sebagai sebuah wadah bagi mualaf dalam mengayomi kebutuhan bersama mendapatkan kepercayaan oleh Baitul Mal Aceh dalam penyaluran dana bagi para mualaf. Adanya Formula ini menjadi lembaga perantara yang bagus sehingga dapat membantu penyaluran dana bagi mualaf secara terorganisir. ${ }^{18} \mathrm{Hal}$ ini sangat

18 Yusran, S, “Kontribusi Baitul Ml terhadap Pemberdayaan Ekonomi Mualaf Berbasis Zakat di Provinsi Aceh", Tesis, UIN Sunan Kalijaga Jogjakarta, 2018. hlm. Xxii. 
membantu para mualaf di Aceh untuk mengembangkan perekonomian mereka sehingga dapat mengembangkan kehidupan.

Langkah lanjutan setelah dibentuk sebuah wadah yang terorganisir adalah upaya peningkatan kemampuan anggota dalam bentuk pelatihan maupun hal lain. Sebagai upaya pengembangan kemampuan melalui kerjasama dengan pemerintah Kota Padang dengan menggunakan program Balai Latihan Kerja (BLK). Melalui program BLK mualaf dapat dilatih dalam upaya persipan mencari maunpun mnciptakan lapangan kerja sesuai dengan kegiatan pelatihan maupun pembinaan yang diikuti. Dalam penentuan peserta yang akan mengikuti program pelatihan berdasarkan rekomendasi dari forum mualaf. Tujuannya adalah agar peserta yang dikirimkan dapat disesuikan dengan kebutuhan mualaf berdasarkan pada database yang telah dibuat.

Gambar 3. Skema Pelatihan BLK

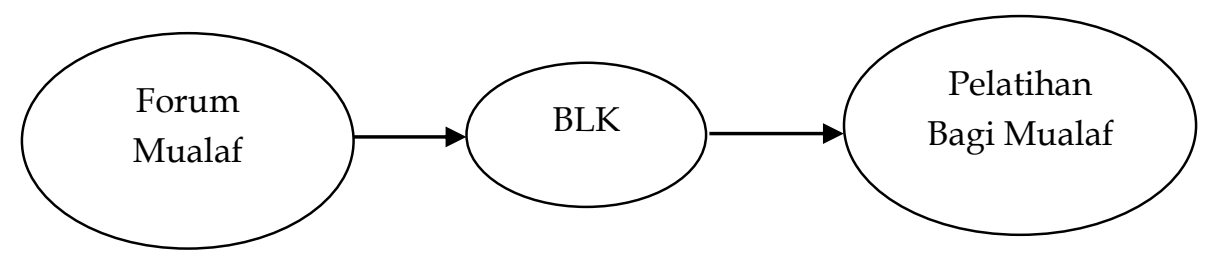

Sumber: Analisis peneliti, 2019.

Beberapa penelitian menunjukkan BLK memiliki peranan dalam meningkatkan kualitas tenaga kerja. Penelitian Ami Ade Maisyarah, ${ }^{19}$ menunjukan UPTD BLK Kalianda sudah mampu meningkatkan kualitas tenaga kerja. Peran balai latihan kerja dalam meningkatkan kualitas tenaga kerja: pengetahuan, keterampilan, albilities sudah dapat terpenuhi, pengetahuan tenaga kerja bertambah, tenaga kerja menjadi lebih terampil, dan abillities (loyalitas, kerjasama. kedisiplin, tanggung jawab) tenaga kerja bertambah, serta tenaga kerja dapat bekerja sesuai dengan keahliannya. Kemudian, penelitian Yanti Ritonga,20 dari penelitian yang dilakukan jumlah tamatan Balai Latihan Kerja Provinsi Bengkulu dari tahun 2000 sampai 2007 berturutturut adalah 138 orang, 145 orang, 130 orang, 160 orang, 140 orang, 140 orang, 160 orang, 230 orang. Sedangkan jumlah tamatan yang bekerja dari tahun 2000 sampai tahun 2007 berturut-turut

${ }^{19}$ Ami Ade Maisyarah, “Analisis Efektivitas Peran Balai Latihan Kerja (BLK) dalam Meningkatkan Kualitas Tenaga Kerja Menurut Prespektif Ekonomi Islam (Studi pada UPTD Balai Latihan Kerja (BLK) Kalianda)", Skripsi, UIN Raden Intan Lampung, 2018. hlm. i.

${ }^{20}$ Lola Yanti Ritonga, "Peranan Balai Latihan Kerja terhadap Penyediaan Tenaga Kerja di Bengkulu”, Skripsi, Universitas Bengkulu. 2009. 
adalah 60 orang, 75 orang, 60 orang, 80 orang, 70 orang, 70 orang, 85 orang, 113 orang. Adapun rata-rata persentase tamatan yang bekerja adalah 49,19.

Jika digambarkan secara lengkap maka strategi pengembangan ekonomi mualaf yang dapat dilakukan adalah sebagai berikut :

Gambar 4. Skema Pengembangan Ekonomi Mualaf

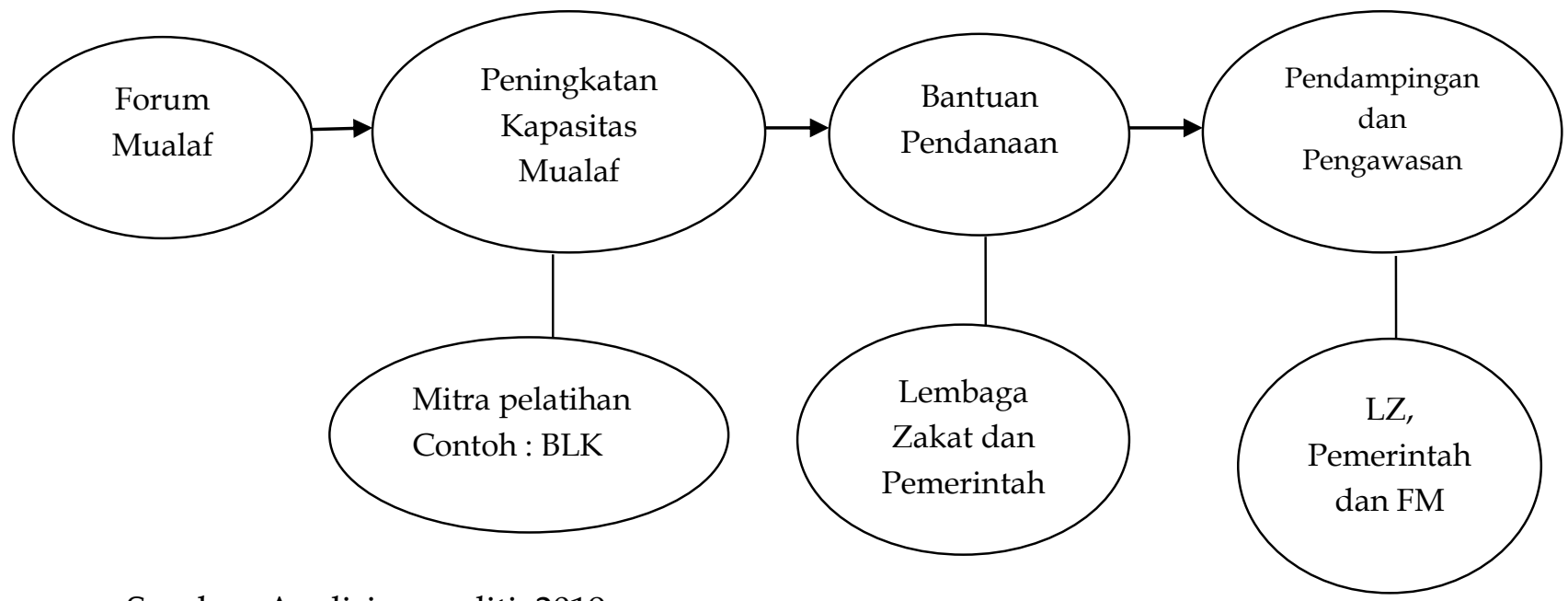

Sumber: Analisis peneliti, 2019.

\section{KESIMPULAN}

Peneliti telah menemukan beberapa problematika ekonomi yang dihadapi oleh mualaf di Kota Padang. Probelmatika tersebut adalah pemutusan hubungan keluarga, rendahnya kemampuan, belum adanya organisasi mualaf, minimnya bantuan dan minimnya kepedulian masyarakat. Dalam upaya menyelesaikan permasalahan tersebut, terdapat empat strategi pengembangan ekonomi mualaf yang dapat dilakukan. Pertama, pembuatan organisasi mualaf sebagai sarana dalam mengumpulkan mualaf dan menjadi problem solving untuk semua mualaf yang ada di Kota Padang. Kedua, peningkatan kapasitas dilakukan dengan mengadakan pelatihan-pelatihan yang memberikan kemampuan pada muallaf sehingga muallaf mempunyai peluang dalam membuat usaha.

Selanjutnya ketiga, pemberian bantuan dana bertujuan agar kemampuan wirausaha yang telah dilatih dapat diimplementasikan dalam bentuk usaha melalui bantuan dana baik dari pihak pemerintah maupun swasta. Keempat, pengawasan serta pendampingan terhadap usaha yang dijalankan oleh mualaf agar dapat bertahan dan dikembangkan sehingga bisa membantu muallaf lain. Disebabkan kajian ini merupakan kajian pencarian strategi maka untuk melihat efek dari konsep yang ditawarkan, diperlukan implementasi dari semua strategi tersebut. Tujuannya 
adalah agar strategi tersebut dapat dinilai dan dievaluasi dalam upaya peningkatan ekonomi mualaf di Kota Padang.

\section{DAFTAR RUJUKAN}

Alfenia. “Gambaran Religiusitas Individu yang Menjalani Konversi Agama Lain ke Islam (Mualaf) di Kota Padang". Thesis, Universitas Andalas, 2018.

Azizah, Rosyida Nur. “Sikap Keberagamaan Mualaf Di Kabupaten Banyumas (Studi Fenomenologi)", Tesis, IAIN Purwokerto, 2018.

Fitriyani, Andi dkk, "Pendampingan dan Pembinaan Komunitas Mualaf melalui Pembibitan Perangkat Syara' di Desa Wamana Baru Kec. Fena Leisela Kab. Buru, Maluku", Dialektika: Jurnal Pemikiran Islam dan Ilmu Sosial, Vol. 12, No. 01, 2019.

Hakiki, Titian., dan Rudi Cahyono. "Komitmen Beragama pada Mualaf (Studi Kasus pada Mualaf Usia Dewasa)", Jurnal Psikologi Klinis dan Kesehatan Mental, Vol. 4, No. 1, 2015.

Hidayati, Sri. "Problematika Pembinaan Mualaf di Kota Singkawang dan Solusinya melalui Program Konseling Komprehensif", Jurnal Dakwah. Vol. XV, No. 1, 2014.

Hutomo, Mardi Yatmo. "Pemberdayaan Masyarakat dalam Bidang Ekonomi", Yogyakarta: Adiyana Press, 2000.

Kholisotin, Lilik., dan Wida Kusniawati, "Problematika Mualaf dalam Melaksanakan Ajaran Islam Didesa Tumbang Runen Kecamatan Kamipang Kabupaten Katingan”, Jurnal Hadratul Madaniyah, Vol. 5, No. 1, 2018.

Maisyarah, Ami Ade. “Analisis Efektivitas Peran Balai Latihan Kerja (BLK) Dalam Meningkatkan Kualitas Tenaga Kerja Menurut Prespektif Ekonomi Islam (Study Pada UPTD Balai Latihan Kerja (BLK) Kalianda)", Skripsi, UIN Raden Intan Lampung, 2018.

Muhdhori, Hafidz. "Treatment dan Kondisi Psikologis Mualaf", Jurnal Edukasi: Media Kajian Bimbingan Konseling, Vol. 3, No. 1, hlm. 16-39.

Mukhtar. "Metode Penelitian Deskriptif Kualitatif", Jakarta: GP Press Group, 2013.

Nawawi, Hadari., dan Mini Martini, "Penelitian Terapan”, Yogyakarta: Gajah Mada University Press, 1996.

Prihartanto, Lucky. “Komitmen Religius Mualafyang Mengikuti Program Pembinaan Mualaf di Masjid Nasional Al-Akbar Surabaya (Ditinjau dari Teori Religious Commitment Stark dan Glock)", Tesis, Uin Sunan Ampel Surabaya, 2018. 
Ritonga Yanti, Lola. "Peranan Balai Latihan Kerja terhadap Penyediaan Tenaga Kerja di Bengkulu", Skripsi, Universitas Bengkulu. 2009.

S, Yusran. "Kontribusi Baitul Ml terhadap Pemberdayaan Ekonomi Mualaf Berbasis Zakat di Provinsi Aceh", Tesis, UIN Sunan Kalijaga Jogjakarta, 2018.

Saprillah. "Pengelolaan Mualaf dan Problematikanya di Kota Palu", Jurnal Al-Fikr, Vol. 20 No. 2, 2016.

Sartika, Mila. "Pengaruh Pendayagunaan Zakat Produktif terhadap Pemberdayaan Mustahiq pada LAZ Yayasan Solo Peduli Surakarta”, La Riba: Jurnal Ekonomi Islam, Vol. II, No. 1, 2008.

Supriadi. "Problematika Mualaf Dalam Melaksanakan Ajaran Agama Islam Di Desa Tumbang Runen Kecamatan Kamipang Kabupaten Katingan”, Jurnal Hadratul Madaniyah, Vol. 5, No. $1,2014$.

Syarifah, Hidayatus. "Pendidikan Agama Islam Bagi Mualaf Di Pesantren Pembinaan Mualaf Yayasan An-Naba Center Indonesia”, Tesis, UIN Syarif Hidayatullah Jakarta, 2017.

Wulansari, Sintha Dwi. "Analisis Peranan Dana Zakat Produktif terhadap Perkembangan Usaha Mikro Mustahik (Penerima Zakat) (Studi Kasus Rumah Zakat Kota Semarang)”, Diponegoro Journal Of Economics, Vol. 3, No. 1, 2014. 